\title{
Feeling in Responding Advertising Exposure on YouTube: The Moderation Influence of Online Experience
}

\author{
Tri Weda RAHARJO*
}

\begin{abstract}
The use of YouTube as a medium of social networking to promote the products proved to be quite effective, yet sometimes it can cause disruption to the users. It is due to the advertisement has interrupted the streaming activity, causing annoyance and displeasure followed by avoidance. Regarding with the problem, this study examined the feelings while response to ad impressions on YouTube. The population of the study is including the YouTube users in Indonesia. Questionnaires used for collecting data which is involving 105 samples of 263 samples that had been spread on colleges and government offices in Surabaya. From the results of this study, it can be concluded that: (1) ad intrusiveness significantly affect ad irritation; (2) online experience does not significantly provide impact in weakening the relation among ad intrusiveness and ad irritation; (3) online experience significantly impact on weakening the relation among ad intrusiveness and ad avoidance; (4) ad intrusiveness significantly affect ad avoidance; (5) ad irritation significantly affect ad avoidance; (6) ad avoidance does not significantly affect the attitude toward the brand.
\end{abstract}

Keywords: Ad Intrusiveness, Ad Irritation, Ad Avoidance, Attitude toward Brand, Online Experience

\section{Introduction}

Nowadays, the existence of internet in societies which exists in line with the globalization, have made it such an important thing. The usefulness reflects on daily activities to business activities that can generate profit. Among the various activities that are supported by the presence of the Internet, one of the activities that gained quite a lot of people's preference is access to a variety of social media services. Social media classification as a tool for commercial necessary are divided into six kinds including social bookmarking, sharing media content, social networks, voting sites, blogs, and micro blogs (Boyd and Ellison, 2007; Singh, Veron and Cullinane, 2008).

Further, social media existence has been provide good advantageous in build brand reputation, knowledge's sharing, and marketing utilities (Kaplan and Haelein, 2010; Bolotaeva and Cata, 2010).

* Research and Development Agency, East Java, Indonesia, triweda03@gmail.com. Orcid ID: 0000-0002-1298-1454 
Therefore, social media marketing appears as system which allows the marketers for interacting and also utilizes many resources collectively for marketing importance. This system has integrated the social media principles along with marketing elements communications in an effort to create a strong and lasting relationship (Chikandiwa, Contogiannis and Jembere, 2013).

Before digital era, to advertise products through television, radio, or newspapers need much cost. But, for now, by utilizing social media, advertising the products do not need to cost a lot of money, just simply create an account, activate and do direct promotion in certain social media. In the recent years, social networking sites such as YouTube, Twitter, Facebook, MySpace, LinkedIn and Friendster have become an integral part in everyday live.

The large numbers of network users have opened new loop holes for media marketing. Thus, the conventional system has developed into online system with software development and networking in particular such as social networking: YouTube. Previously, it has been known that, to establish an online sales system need a lot cost of money, but nowadays anyone can utilize YouTube as marketing place. It does not require sophisticated information technology since basically this media merely show the items through video content.

Brands could easily deliver their marketing messages and reach the target market through YouTube. The supremacy of YouTube video content for marketing activity is that the video may turn into viral. In simple definition, viral marketing can be described as a strategy that uses the concept of viral techniques (such as viruses) to hook a huge visitors through the impression of content. Hence, it will lead the visitors to share the video which has captured his/her attention on other social media platforms and also numerous accounts. For instance, when a person watches a funny video in YouTube, unconsciously, the person will be impressed and shared the video to their community via another social media, such as Instagram, Twitter, WhatsApp, or even Facebook.

Thus, viral marketing technique is considered to be the primary key for brands to be existed in cyberspace up to now. However, such a brand needs to pay attention to the business pillars in social media, hence the advantageous of YouTube as well as another social media networks can be obtained for information exchange and self-branding. Moreover, the users also can express its own argument or opinion, praise as like in direct communication (Andre, Bernstein, and Luther, 2012, pp. 36-37).

In this case, YouTube depicted as a website that provides a wide range of video from video clips or even movies. YouTube has several benefits for its users such as for entertainment and sharing knowledge by uploading variety of useful tutorials. Moreover, it can be used also for market products, by uploading video contents related to products, services or corporate brands, so therefore it can be regarded as free advertising.

\section{Literature Review}

Several studies have been conducted in relation with perceived ad intrusiveness. Thus, the result showed that several dimension are exist including: disturbances on individual's privacy (Sipior and Ward, 1995), cognitive, task performance (Li, Edwards and Lee, 2002) and content media (Ha, 1996). 
According to the dimensions above, ad intrusiveness can be described as the level of unrequested communications interferes with the individual's cognitive and tasks performance and offensive material. Another aspect of ad intrusiveness is represented by interference performance of one's duties namely the person's cognitive processing. Ad intrusiveness is social media users' cognitive process which assumes ad as disturbing and distracting the thoughts or activities (Li, Edwards and Lee, 2002; pp. 37-47). From the foregoing description, it can be concluded that ad intrusiveness is cognitive processes disorder of the social media users generated by advertising.

Furthermore, the disruption caused by the perceived intrusiveness will rise to dissatisfaction with the ad called as ad irritation. Ad irritation as proposed by Aaker and Bruzzone (1985) is dissatisfaction, impatient, and unpleasant stimuli caused by various forms of advertising (pp. 4757). It can be concluded that ad irritation is negative feelings or unpleasing feeling brought about by stimulus advertising.

The result of several previous studies showed that some potential factors able to trigger the ad irritation and ad intrusiveness on the advertised products (Aaker and Bruzzone, 1985; Aaker and Norris, 1982; De Pelsmacker and Van den Bergh, 1998; Li, Edwards, and Lee, 2002; Fennis and Bakker, 2001; Friz, 1979; Ha, 1996; Li, Edwards, and Lee, 2002; Stayman and Aaker, 1988). Ad irritation has also described to be the first reaction of consumers towards advertising (Aaker and Bruzzone, 1985; Aaker and Stayman, 1990; De Pelsmacker and Van den Bergh, 1998). However, ad irritation always leads to more negative attitudes on advertising and dissatisfaction of social media users caused by stimulation of the advertising (De Pelsmacker and Van den Bergh, 1998, p. 6).

In facing the problem dealing with ad intrusiveness and ad irritation, social media users may try to withdraw from the disturbing ad by doing ad avoidance. Thus, ad avoidance can be defined as all the actions performed by the users to avoid exposure to advertising (Speck and Elliott, 1997a, p. 61).

The relationship among ad intrusiveness, ad irritation and ad avoidance need to be investigated for the following reasons: first, ad intrusiveness is considered as thing that easily capture people's attention, such as the existence of billboards which disturbing the pedestrian (Vespe, 1997, pp. 176179). In a recent study on consumers in the United States, Bauer and Greyser (1968) acknowledged that the ad intrusiveness is a primary cause of irritation to the advertising (pp. 3-7). Although, advertisers sometimes prefer consumers, hence, consumers tend to form negative behavior towards this tactic. This negative behavior then will affect the perception and behavior towards the brand (MacKenzie and Lutz, 1989) and sometimes leads to the rejection of the advertisement (ad avoidance) (Abernethy, 1991; Clancey, 1994; Krugman and Johnson, 1991).

In addition, Rust and Varki (1996) give opinion that advertising on the media will be less interfere due to interactiveness (pp. 173-191). Yet, several studies have noted that online advertising is irritating (Reed, 1999, pp. 25-26). It can be seen in the new tactics such as pop-up ads that isolate users as passive viewers of a forced message, the same as advertising on television. Ad intrusiveness has been addressed in several studies (Bauer and Greyser, 1968; Greyser, 1973; Ha, 1996; Pollay, 1986), but it is still not optimal yet (Li, Edwards, and Lee, 2002). 
The study related to the relationship between ad intrusiveness, ad irritation and ad avoidance conducted by Li, Edwards, and Lee (2002) showed that the relationship among variables is that one of five relationships proved to be insignificant, i.e between ad intrusiveness and cognitive ad avoidance (pp. 37-47).

The description dealing with the relationship among ad intrusiveness and ad avoidance, showed that ad intrusiveness lead to the rejection on the advertisement (Abernethy, 1991; Krugman and Johnson, 1991; Clancey, 1994). It means that the relationship between ad intrusiveness directly related to the ad avoidance. Hence, there is insignificant relation between ad intrusiveness and cognitive ad avoidance which strength the reason to conduct research about ad irritation, ad intrusiveness and ad avoidance.

Feeling on the brand is including the response of the consumers whether please or unpleasing to the brand after the ads stimulus delivered to someone (Phelps and Hoy, 1996, p. 79). As the conception of the relationship between elements in the Model Attitude-Toward-Ad proposed by Schiffman and Kanuk (2007), that the cognitive component represents the probability of an individual will perform certain actions or behave in a certain way with regard to the attitude object. Meanwhile, ad avoidance is the actions performed by users in different media that reduce the exposure to advertising content. Thus, the ad avoidance influences the attitude toward advertising.

Hwang, Yoon and Park (2011) found that the response to the advertising is positively associated with attitudes website, while the web site attitudes will positively affect attitude toward the brand. Ad avoidance is a form of negative attitudes toward advertising. Furthermore, Schiffman and Kanuk (2007) states that attitude toward advertising influences the attitude toward the brand. So it can be said that ad avoidance affects the attitude toward the brand (p. 210).

Individual's experience in using online media will affect their feelings while facing the disruption caused by the perceived intrusiveness. Online experience is including several elements such as browsing, selecting, finding, and evaluating information, and interacting as well as transact with the online company (Constantinides, 2004, pp. 111-121).

User experience is dynamic, constantly changing from time to time due to the different change in use and individual change systems as well as the broader context of the use they could find. Organism refers to the organic experience of individuals that includes the flow, engagement, cognitive networks, schemes, and so on Li, Edwards, and Lee (2002) argues that consumers learning from the experience by interacting with their environment (pp. 37-47).

Moreover, Keng, Smoski and Robins (2011) have classified the online experience into two kinds: (1) direct product experience; and (2) indirectly product experience. Direct product experience occurred when users obtain information directly interact with the product. Meanwhile, indirectly product experience occurred when the user experiencing product through advertising (p. 1045). In particular, product experience will lead the user or consumer to do future purchasing (Spudich and Chiou, 2008, p. 280). Thus, the response can be in many forms from please or unpleasing reaction and of internal to external. 
According to Constantinides (2004) the main elements of the online experience or web experience are as follows: (1) the functionality of the website which includes elements relating to usefulness and interactivity of the website, (2) the psychological elements that are intends into reduce consumer uncertainty over the trust and credibility communications on online vendors and website, (3) the content elements include aesthetic aspects of the presentation and the marketing mix (p. 112). These three factors are including into major marketing tool marketers who are in control of electronic (e-marketers) (Constantinides, 2004, p. 121). The description is a perspective view of a marketer. Meanwhile, from the perspective of the consumer or user, according to the online research experience with reference to the opinion of Dzaujak (2004) is a person's performance in using social media YouTube based on its duration, level of frequency as well as the type and number of results (information) which has been obtained. Thus, a person's online experience describes based on the using of online media using relate to the duration, level of frequency as well as the type and number of results (information) which has been obtained (p. 57).

A person, who is experience in using online media (in this case, YouTube) for a long duration time, will be accustomed to overcome the ad intrusiveness, ad irritation, ad avoidance. Hence, it will lead more on accommodating to advertise on YouTube since the accommodative attitude towards advertisement will facilitate their acceptance of the brands advertised. It is in line with MacKenzie, Lutz, and Belch's (1989) statement that, the negative behaviors which are influenced by the intrusiveness will affect the perception and behavior towards the brand perception and feelings (pp. 48-65).

\section{Method}

\section{Model of Research}

The model developed in this study is explained in the figure below. It is divided into two models: model 1 without moderation online experience. Meanwhile, model 2 includes the influence of the online experience.

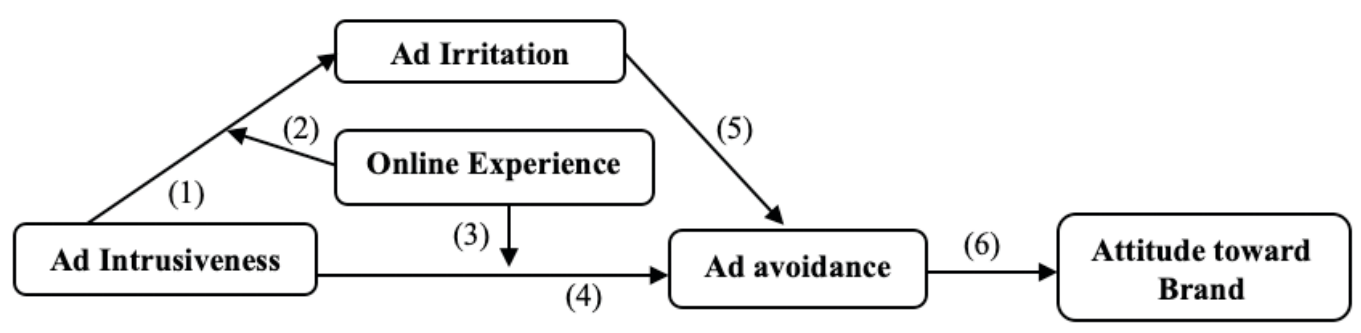

Figure 1. Conceptual Framework 
Ad intrusiveness is a disorder of cognitive processes in social media user generated by advertising. The measurement of this variable refers to research conducted by Li, Edwards and Lee (2002), with only took four indicators from eight indicators, namely: (1) bothersome; (2) intrusive; (3) forced and (4) distracting. Each indicator is measured using Likert scale research and provided five answer options, which the lowest answers rated 1 and the highest rated 5, by the type size is interval. On these indicators, the higher the value then more negative the numbers which indicating indicator assessment of the indicator.

Ad irritation is users' negative or unpleasant feeling toward social media YouTube caused by stimulation of the ad. The measurement of this variable refers to research conducted by Aaker and Bruzzone (1985), with the indicators: (1) annoyance with the duration of ad; (2) annoyance with the frequency of ad exposure; (3) uncomfortable with the content of ad; and (4) uncomfortable with the sound generated ad impressions (pp. 47-57). Each indicator is measured using Likert scale research and provided five answer options, which answers the lowest rated 1 and the highest rated 5 , the type size of the interval. On these indicators, the higher the value the more negative numbers indicating indicator assessment of the indicator.

Ad avoidance is all different action to avoid or reduce to advertising content exposure on YouTube. By adopting the opinion of Speck and Elliott (1997a) ad avoidance depicted as cognitive and behavioral, the indicator variables include: (1) see some ads served then click on the ads; (2) allow the ads served without seeing it; and (3) close the ads served (pp. 61-76). Each indicator is measured using Likert scale research and provided five answer options, which the lowest answers, rated 1 and the highest rated 5, the size type is interval. The higher the value of the variable numbers indicating more negative assessment of this indicator.

Online experience is one's experience in using social media YouTube based on duration, level of frequency, and type and number of results (information) which has been obtained, with under reference Djauzak (2004), the factors that affect the experience include: time, frequency, and application. So that, the indicators of this variable are: (1) period in using; (2) frequency in using; and (3) the main media used to get information (p. 57). Each indicator is measured using Likert scale research and provided five answer options, which the lowest answers rated 1 and the highest rated 5 , with the size type is interval. On these indicators, the higher the numerical value indicates more positive indicators on the indicator assessment.

Attitude toward the brand is a tendency to respond in a way that is favorable or unfavorable to the particular brand after stimulus delivered ads. With reference to the research conducted by Kruger, Kühn, Petzer and Mostert (2013), the indicators of these variables include: (1) brand which promoted are quite good; (2) trust in the promoted brand (3) please with the promoted brand; and (4) prefer to use promoted brands. Each indicator is measured using Likert scale research and provided five answer options, which answers the lowest rated 1 and the highest rated 5 , the type size of the interval. On these indicators, the higher the numerical value indicates more positive indicators on the indicator assessment. 
Regarding with the explanation of model research above, this study used quantitative explanatory which aims to analyze the relationships between variables and explain the influence between variables through hypothesis testing. These variables are: ad intrusiveness, ad irritation, ad avoidance, online experience, and attitude toward the brand.

The population in this study was taken from YouTube users in Indonesia. The sampling technique used was purposive sampling and accidental sampling which is combined to be purposive accidental techniques. This sample technique use some consideration based on chance or coincidentally met the researchers following several respondents criteria: (1) the Indonesian society; (2) 17 years old or more; (3) doing video streaming activities via YouTube for the last two weeks; and (4) seeing ads while video streaming on YouTube. Then, the primary analysis used to determine the effect is Structural Equational Modelling (SEM) analysis.

\section{Results}

\section{Description of the Research Object}

In this study, the Internet users in the government offices circumstance and/or in the campus area in Surabaya are chosen as respondents. The reason to choose those respondents are due to the majority of YouTube users are Indonesian women aged between17-21years. Most of the respondents were users of YouTube with high school education background and undergraduates, university students and civil servants. Furthermore, most of the respondents were stay in big cities. It showed that the development of internet technology today is rapid and has already reached into various areas, especially large cities, especially Surabaya as big city in Indonesia. From 105 of the 263 people surveyed, was selected as the respondent in accordance with the criteria of screening in this study. A description of the character of the respondent is important as the initial information that supports the results of research conducted on YouTube users.

Table 1. Sex and Age

\begin{tabular}{|c|c|c|}
\hline Criteria & Frequency & Percentage \\
\hline \multicolumn{3}{|l|}{ Sex } \\
\hline Male & 43 & 41.0 \\
\hline Female & 62 & 59.0 \\
\hline Amount & 105 & 100.0 \\
\hline \multicolumn{3}{|l|}{ Age } \\
\hline $17-21$ & 53 & 50.5 \\
\hline $22-26$ & 23 & 21.9 \\
\hline $27-31$ & 10 & 9.5 \\
\hline $32-36$ & 6 & 5.7 \\
\hline $37-41$ & 4 & \begin{tabular}{|l|l}
3.8 \\
\end{tabular} \\
\hline $42-46$ & 3 & 2.9 \\
\hline $47-51$ & 2 & 1.9 \\
\hline $52-56$ & 4 & 3.8 \\
\hline Amount & 105 & 100.0 \\
\hline
\end{tabular}


Table 1 showed that from 105 YouTube users in Indonesia, it was about 43 people (41\%) are male and $62(59 \%)$ are women. The age range in this study restricted from 17 years to 56 years, in which the majority $(50.5 \%)$ were aged17-21 years YouTube users. Then YouTube users aged 22-26 years (21.9\%) and 27-31years (9.5\%).

Table 2. Education

\begin{tabular}{|l|l|l|}
\hline Education & Frequency & Percentage \\
\hline Criteria & 65 & 61.9 \\
\hline High school education & 3 & 2.9 \\
\hline Bachelor & 27 & 25.7 \\
\hline Graduate & 10 & 9.5 \\
\hline Post-graduate & 105 & 100.0 \\
\hline Amount & & \\
\hline
\end{tabular}

The age of population were dominated by the range of 17-21years are suitable for review based on educational background. Mostly the ages were educated high school (61.9\%). Then, about 27 people Undergraduate (27\%), Post graduate (9.5\%), and the least are Diploma III which only three people (2.9\%).

Tabel 3. Occupations and Residences

\begin{tabular}{|l|l|l|}
\hline Criteria & Frequency & Percentage \\
\hline Occupation & \multicolumn{2}{l|}{} \\
\hline Entrepreneurs & 5 & 4.8 \\
\hline Employees & 9 & 8.6 \\
\hline Civil servants & 32 & 30.5 \\
\hline Honorary & 1 & 1.0 \\
\hline Student & 58 & 55.2 \\
\hline Amount & 105 & 100.0 \\
\hline Residence & \multicolumn{2}{|l|}{} \\
\hline Village & 25 & 23.8 \\
\hline Medium-sized cities & 33 & 31.4 \\
\hline Urban & 47 & 44.8 \\
\hline Amount & 105 & 100.0 \\
\hline
\end{tabular}

From Table 3, based on the occupations which are around 55.2\% of the 105 YouTube users surveyed were students. Meanwhile, $30.5 \%$ are working as civil servants. The rest are private sector employees (8.6\%), entrepreneurs (4.8\%), and honorary (1\%). Based on the residence, the majority of YouTube users surveyed live in large urban areas (44.5\%), 31.4\% medium-sized cities, and 23.8\% in villages. 
Table 4. Streaming Purpose

\begin{tabular}{|l|l|l|}
\hline Criteria & Frequency & Percentage \\
\hline Streaming purpose & \multicolumn{2}{l|}{} \\
\hline News & 1 & 1.0 \\
\hline News; Certainty Information & 1 & 1.0 \\
\hline Entertainment & $\mathbf{6 4}$ & $\mathbf{6 1 . 0}$ \\
\hline Entertainment; Entertainment & 5 & 3.8 \\
\hline Entertainment; News; Certainty Information & 6 & 5.7 \\
\hline Entertainment; Certainty Information & 12 & 11.4 \\
\hline Certainty Information & $\mathbf{1 7}$ & $\mathbf{1 6 . 2}$ \\
\hline Total Amounts & 105 & 100.0 \\
\hline
\end{tabular}

The majority of respondents' purpose in streaming YouTube is for entertainment (61\%) and certain information (16.2\%). This is supported by the rapid technological development in various areas, especially large cities with the different life style with intermediate cities or even villages, so that the level of activity of mobile and internet access can also be obtained easily and even facilitated for free.

\section{Model 1}

This model is a model without moderating online experience. The results show as the picture below:

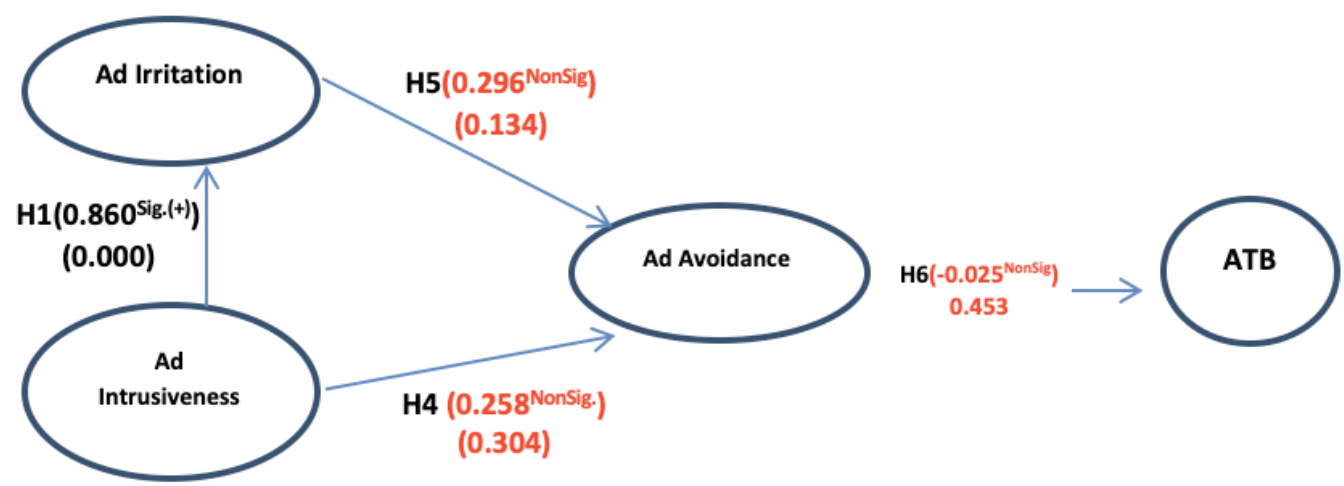

Figure 2. Models without moderation of Online experience

In Figure 2 above shows the relationship between variables as follows: (1) Ad intrusiveness significantly influence ad irritation on advertising for users of social networking YouTube; (2) Ad intrusiveness does not significantly influences the ad avoidance on advertising for users of social networking YouTube; (3) Ad irritation does not significantly influence the ad avoidance on advertising for users of social networking YouTube (4) Ad avoidance does not significantly influence the attitude toward the brand in the advertising for users of social networking YouTube. 


\section{Model 2}

This model is a model with online experience moderation. The results show as follows:

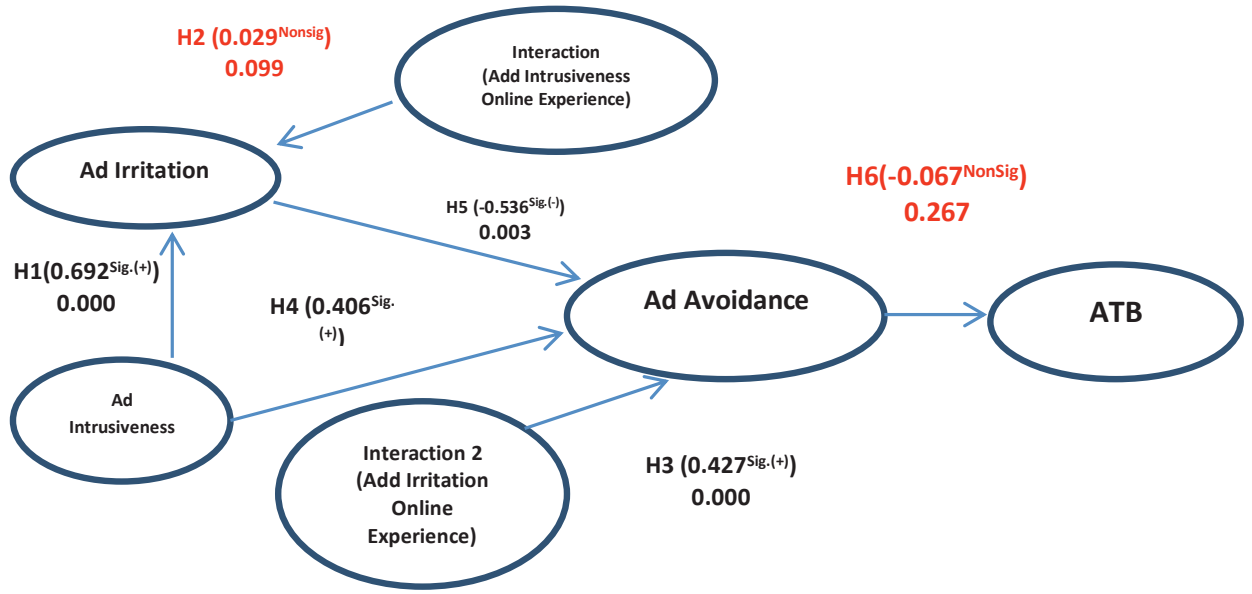

Figure 3. Models with moderation of online experience

In Figure 3 above, it indicates several matters: (1) Ad intrusiveness significantly affect ad irritation on product advertising for users of social networking YouTube; (2) Online experience does not have significant effect in weakening the relationship of ad intrusiveness and ad irritation on product advertising for users of social networking YouTube; (3) Online experience significantly weaken the relationship of ad intrusiveness and the avoidance on product advertising for users of social networking YouTube; (4) Ad intrusiveness significantly influence ad avoidance on product advertising for users of social networking YouTube; (5) Ad irritation significantly influence ad avoidance on product advertising for users of social networking YouTube; (6) Ad avoidance does not significantly influence the attitude toward the brand in the product advertising for users of social networking YouTube.

\section{Discussion}

Results of hypotheses testing (H1) indicates that the ad intrusiveness impacts positively on the ad irritation. In more detail, it is known that the indicator intrusive (x1.2) of most respondents reflect on ad intrusiveness, this condition indicates that the ad intrusiveness most felt by YouTube users on ad serving mainly because of intrusive. Meanwhile, the indicator that dominates ad irritation condition is the duration or period (x2.1). Ads that interfere with the process of programming the consumers or editorial content in the media environment will cause irritation of the ads that will be welcomed. Feelings of irritation may increase to the extent that annoying ads because of their execution (i.e., too hard or too long) or placement (i.e., too much or too often). 
Results of testing the hypothesis $(\mathrm{H} 2)$ suggests that the online experience has no significant effect in weakening the relationship of ad intrusiveness to the ad irritation. In more detail, it is known that the interaction between ad intrusiveness with online experience shows that the most dominant indicator intrusive (x1.2) interactions with a frequency of access (x3.2). Meanwhile, the indicator that dominates ad condition irritation is the duration $(\mathrm{x} 2.1)$. The result which states that online experience has no significant role in moderating influence on the ad intrusiveness irritation can be explained with the opinion of Huang (2003). Huang states that online experiences involve the desire or willingness to browse or interact with the web. During exploration, some interaction occurs between the user and the web, which may involve the user to spend time reading the text or looking at the graph, or could involve questioning the user to complete the transaction or database (pp. 22232253).

Results of hypotheses testing (H3) showed that online experience has a moderating role to influence the relationship between ad intrusiveness with ad avoidance. In more detail, it is known that the interaction between ad intrusiveness with online experience shows that the most dominant indicator interaction intrusive (x1.2) with a frequency of access (x3.2). Meanwhile, the indicator that dominates ad avoidance is by immediately closed the ads that appear during streaming YouTube (y1.3). Thus, the online experience weakens the influence of ad intrusiveness relationship towards ad avoidance. Referring to the opinion of Djauzak (2004), is a person's performance in using online media based on its duration, level of frequency also the type and number of results (information) which has been obtained, thus someone who has more experience would reduce rejection of ad impressions that disturb them.

Results of hypothesis testing (H4) showed that ad intrusiveness positively impacts on ad avoidance. Ad intrusiveness character is reflected by the most intrusive indicator (x1.2). Meanwhile, the indicator that dominates ad avoidance condition is closed immediately the ads that appears on YouTube (y1.3). So, the psychological consequences that arise from Internet users on Youtube ad serving is boredom. This boredom turned out to cause a reaction in the form of behavioral ad exposure which directly closes pop-up ads on YouTube. The results are in line with the results of the study by Li, Edwards and Lee (2002), which indicates that there is a significant relationship between ad intrusiveness and behavioral ad avoidance (pp. 37-47). Also, in line with Cronin and Menelly (1992) described that viewers who might avoid ads while recognition of what happened, not in specific ad content (pp. 1-7). They generally do not distinguish between ads that they avoid the ads they watch; they just avoid all the ads (Abernethy, 1991, pp. 223-231).

Results of hypotheses testing (H5) indicate that ad irritation impact negatively on ad avoidance. Indicators ad irritation that most reflects his character is the duration (x2.1), in other words the reaction of most ad irritation felt by YouTube users on ad serving mainly because of the duration of the ad is. While the indicator that dominates ad avoidance condition is immediately closed ads that appear on YouTube (y1.3).The negative sign on the path coefficient means higher ad caused irritation on ads on YouTube, then the lower the ad avoidance reaction YouTube users on the ad. The results are in line with the results of Li, Edwards and Lee (2002), that there is a significant relationship 
between ad irritation and cognitive ad avoidance and as well as a significant correlation between ad irritation and behavioral ad avoidance (pp. 37-47).

Afterward, the results of hypothesis testing (H6) showed that ad avoidance has no significant influence on the Attitude toward Brand. These results are in line with the argument expressed by MacKenzie, Lutz and Belch (1986); Olney, Labruyere, Wang, Wozniak, Price and Sesma (1991); and Park, Jaworski, and MacInnis (1986) regarding with the role of advertising in building trust and feeling of the brand. However, there is no significant relationship between ad avoidance and Attitude toward Brand. Thus, it shows that the reaction while seeing ads on YouTube by directly closes pop-up ads does not necessarily affect the attitude of YouTube users to the brand ads they see.

\section{Conclusion}

The use of YouTube as a medium of social networking to promote the products proved to be quite effective, yet sometimes it can cause disruption to the users. It is due to the ads that appear has interrupted the streaming activity, causing annoyance and displeasure followed by avoidance. Thus, the result show that: (1) ad intrusiveness significantly affect ad irritation; (2) online experience does not have a significant effect in weakening the relationship of ad intrusiveness of the ad irritation; (3) online experience significantly weaken the relationship of ad intrusiveness toward the ad avoidance; (4) ad intrusiveness significantly affect ad avoidance; (5) ad irritation significantly affect ad avoidance; (6) ad avoidance does not significantly affect the attitude toward the brand.

In addition, for further researches, it is hoped that the discussion will be used another social media beside YouTube. Since, the advertisements are not merely appear in YouTube, rather it also appear in Instagram, Facebook, as well as Twitter. Hence, the feeling of social media user will be different based on the certain social media they mostly used.

\section{References}

Aaker, D. S. and Bruzzone, D. E. (1985). Causes of irritation in advertising. Journal of Marketing, 49(2), 47-57.

Aaker, D. A and Norris, D. R. (1982) Characteristics of TV commercials perceived as informative. Journal of Advertising Research, 22(2), 61-70.

Aaker, D. A. and Stayman, D. M. (1990). Measuring audience perception of commercial and relating them to ad impact. Journal of Advertising Research, 30(4), 7-17.

Abernethy, A. M. (1991). Physical and mechanical avoidance of television commercials: An exploratory study of zipping, zapping and leaving. In R. Holman (ed.), Proceedings of the American academy of advertising (pp. 223-231). NY: The American Academy of Advertising.

Andre, P., Bernstein, M. andLuther, K. (2012). What makes a great tweet? Harvard Business Review, 90(5), 36-37.

Bauer, R. A. and Greyser, S. A. (1968). Advertising in American: The consumer view. Boston, MA: Harvard University.

Bolotaeva, V. and Cata, T. (2010). Marketing opportunities with social networks. Journal of Internet Social Networking and Virtual Communities, 2010, 1-8.

Boyd, M. D. and Ellison, N. B. (2007). Social network sites: Definition, history, and scholarship. Journal of Computer-Mediated Communication, 13(1), 210-230. 
Chikandiwa, S. T., Contogiannis, E., and Jembere, E. (2013). The Adoption of social media marketing in South African banks. European Business Review, 25(4), 365-381.

Clancey, M. (1994). The television audience examined. Journal of advertising Research, 34(4), S1-S1.

Constantinides, E. (2004). Influencing the online consumer's behavior: the Web experience. Internet Research, 14(2), 111-126.

Cronin, J. J. and Menelly, N. E. (1992). Discrimination vs. avoidance: “Zipping” of television commercials. Journal of Advertising, 21(2), 1-7.

De Pelsmacker, P. and Van den Bergh. J. (1998). Advertising content and irritation: A study of 226 TV commercials. Journal of International Consumer Marketing, 10(4), 5-28.

Djauzak, A. (2004). Peningkatan Mutu Pendidikan Sebagai Sarana Pembangunan Bangsa, Jakarta: Balai Pustaka.

Fennis, B. M. and Bakker, A. B. (2001). "Stay tuned-we will be back right after these messages": Need to evaluate moderates the transfer of irritation in advertising. Journal of Advertising, 30(3), 15-25.

Friz, C. T. (1979). A numerical taxonomic study of six species of the free-living amoeba. Archiv für Protistenkunde, 122(3-4), 360-371.

Li, H., Edwards, S. M. and Lee, J. H. (2002). Forced exposure and psychological reactance: Antecedents and consequences of the perceived intrusiveness of pop-up ads. Journal of Advertising, 31(3), 83-95.

Greyser, S. (1973). Irritation in advertising. Journal of Advertising Research, 13(1), 3-7.

Ha, L. (1996). Advertising clutter in consumer magazines: Dimensions and effects. Journal of Advertising Research, 36(4), 76-84.

Huang, Z. M., Zhang, Y. Z., Kotaki, M. and Ramakrishna, S. (2003). A review on polymer nanofibers by electrospinning and their applications in nanocomposites. Composites science and technology, 63(15), 2223-2253.

Hwang, J., Yoon, Y. S. and Park, N. H. (2011). Structural effects of cognitive and affective reponses to web advertisements, website and brand attitudes, and purchase intentions: The case of casual-dining restaurants. International Journal of Hospitality Management, 30(4), 897-907.

Kaplan, A. M. and Haenlein, M. (2010). Users of the world, unite! The challenges and opportunities of social media. Business Horizons, 53(1), 59-68.

Keng, S. L., Smoski, M. J. and Robins, C. J. (2011). Effects of mindfulness on psychological health: A review of empirical studies. Clinical Psychology Review, 31(6), 1041-1056.

Kruger, L. M., Kühn S. W., Petzer, D. J. and Mostert, P. G. (2013). Investigating brand romance, brand attitude and brand loyalty in the cellphone industry. Acta Commercii, 13(1). DOI: 10.4102/ac.v13i1.178.

Krugman., D. M. and Johnson, K. F. (1991). Differences in the consumption of traditional broadcast and VCR movie rental. Journal of Broadcasting and Electronic Media, (35), 213-232.

Li, H., Edwards, S. M. and Lee, J. H. (2002). Measuring the intrusiveness of advertisements: Scale development and validation. Journal of Advertising, 31(2), 37-47.

MacKenzie, S. B., Lutz, R. J. and Belch, G. E. (1986). The role of attitude toward the ad as a advertising effectiveness: A test of competing explanation. Journal of Marketing Research, 23(2), 130-143.

MacKenzie, S. B. and Lutz, R. J. (1989). An empirical examination of the structural antecedents of attitude toward the ad in an advertising pretesting context. Journal of marketing, 53(2), 48-65.

Olney, J. W., Labruyere, J., Wang, G., Wozniak, D. F., Price, M. T. and Sesma, M. A. (1991). NMDA antagonist neurotoxicity: mechanism and prevention. Science, 254(5037), 1515-1518.

Park, C. W., Jaworski, B. J. and MacInnis, D. J. (1986). Strategic brand concept-image management. Journal of Marketing, 50(4), 135-145. 
Phelps, J. E. and Hoy, M. G. (1996). The Aad-Ab-PI relationship in children: the impact of brand familiarity and measurement timing. Psychology and Marketing, 13(1). 77-101.

Pollay, R. W. (1986). The distorted mirror: Reflections on the unintended consequences of advertising. Journal of Marketing, 50(2), 18-36.

Reed, M. (1999). Going beyond the banner ad. Marketing, (April), 25-26.

Rust, R. T. and Varki, S. (1996). Rising from the ashes of advertising. Journal of Business Research, 37(3), 173-191.

Schiffman, L. G. and Kanuk, L. L. (2007). Purchasing behavior. 207-215.

Singh, T., Veron, J. L. and Cullinane, J. (2008). Blogging: a new play in your marketing game plan. Business Horizons, 51(4), 281-292.

Sipior, J. C. and Ward, B. T. (1995). The ethical and legal quandary of email privacy, Communication of the ACM, 38(12), 48-54.

Speck, P. S. and Elliot, M. T. (1997a). Predictors of advertising avoidance in print and broadcast media, Journal of Advertising, 26(3), 61-76.

Spudich, P. and Chiou, B. S. (2008). Directivity in NGA earthquake ground motions: Analysis using isochrone theory. Earthquake Spectra, 24(1), 279-298.

Stayman, D. M. and Aaker, D. (1988). Are all the effects of ad-induced feelings mediated by AAd? Journal of Consumer Research, 15(3), 368-373.

Vespe, F. (1997). High-tech billboards: The same old litter on a stick. Journal of Public Policy and Marketing, 16(1), 176-179. 